\title{
The impact of the COVID-19 pandemic process on yacht operators: Application on a marina in Antalya
}

Erdal Arlı, İrşad Bayırhan*

\author{
Keywords: \\ COVID-19, \\ Marina Tourism, \\ Yacht Management
}

\begin{abstract}
Since the COVID-19 pandemic emerged, it has had a noticeable negative impact on many sectors and markets, especially the health sector. Although the large scale consequences have not yet been fully determined, the pandemic; started to change business life, personal priorities and habits. Curfews and encouragement of people not to leave their homes disrupted yachting activities. For this reason, one of the business lines most affected by the pandemic in the world has undoubtedly been the marine tourism sector. In countries with many sub-areas for marine tourism, such as Turkey, also in the yachting business sector has experienced a significant decline compared to last years. In this study; the level of exposure of yacht businesses which daily tour organizer and operating in X Marina where in Antalya the one of the most important and sought-after holiday destinations of Turkey, from the COVID-19 pandemic process has been tried to be revealed. In the study, quantitative research method was used and face to face survey technique was used. The most important limitation of this research is that it has been conducted only on yacht enterprises and daily boat tour operating in a single marina. Research results were analyzed with SPSS package program. In the analysis made, it is understood that especially the entrepreneur boat operators are concerned about the future and they are in a pessimistic picture. They stated that if COVID-19 continues, they can quit entrepreneurship and sell their boats and switch to another line of business.
\end{abstract}

Article History:

Submitted: 18.12 .2020

Accepted: 20.04.2021

\section{Introduction}

COVID-19 emerged in the Wuhan region of China in December 2019 and spread rapidly all over the world and was declared as a global "pandemic" by the World Health Organization (WHO) on March 11, 2020. Since its inception, the virus has had a noticeable negative impact on many sectors and markets, especially the health sector. This process, with a rapid domino effect, brought along many socio-economic problems that are expected to be very difficult to return. In fact, the crisis created by COVID-19 is defined as the biggest global crisis since the Second World War (Chakraborty \& Maity, 2020). Although the large scale consequences have not yet been fully determined, the pandemic; started to change business life, personal priorities and habits. In this sense, it is understood that maritime, tourism and related sectors, and especially yacht management as a recreational activity, are among the enterprises most affected by the process (Millefiori et al., 2020; Depellegrin et al., 2020; Gössling et al., 2020;
TKYGM, 2020). Among the most critical issues affecting the international maritime industry during the pandemic; there are problems with closure of ports to ships, crew changes and repatriation problems for seafarers, including those working on cruise ships and yachts, certification and licensing of seafarers, supply and repair problems (Doumbia-Henry, 2020; Stannard, 2020). As a result of all this, there was a $61-62 \%$ decrease in port capacity utilization worldwide in May 2020, mainly due to a decrease in passenger calls (WPSP, 2020; Doumbia-Henry, 2020).

In addition, governments in many countries of the world have had to restrict the movements of their citizens with "quarantine" measures. The uncertainties created by the current situation make the yacht customers uneasy, and the measures taken to combat the epidemic cause capacity reductions. International travel limitation and some other measures cause a serious decrease in the number of tourists (Chebli \& Said, 2020). A contraction is observed in many yacht operating

\footnotetext{
*Corresponding Author

Erdal Arl. Prof. Dr, Istanbul University, Department of Marine Management, Institute of Marine Sciences and Management, Istanbul, Turkey, Email: erdal.arli@istanbul.edu.tr, Orcid Id:0000-0002-7825-0910 iD

Irsad Bayurhan: Res. Asst., , Istanbul University, Department of Marine Environment, Institute of Marine Sciences and Management, Istanbul, Turkey, Email: ibayirhan@istanbul.edu.tr, Orcid Id: 0000-0001-9404-399X iD
} 
companies and a cash shortage arises. Curfews and encouragement of people not to leave their homes disrupted yachting activities. The number of employees in the sector has halved and even this situation has reduced the production capacity below 30\% (TKYGM, 2020). Under pandemic conditions, some sectors have relatively provided the continuity of some workflows with the use of digital infrastructure facilities. However, due to its nature, yacht tourism has been seriously affected by this process with the protection measures and quarantine practices taken in the first place.

For all these reasons, the study aimed to investigate to what extent yacht management, a special area of the tourism and maritime sectors, was affected by the COVID-19 process. The sample of study was the yacht enterprises operating in a marina in Antalya. In this sense, it is thought that the research results will contribute to the literature in terms of determining the effects of COVID-19 on yacht tourism and will give clues to similar yacht business managers.

Antalya, which has become a complete tourism city after the $1950 \mathrm{~s}$, is still one of the most popular holiday destinations in the world. Providing opportunities for many types of tourism and recreation activities in all seasons, Antalya ranked tenth in the ranking of the world's most touristattracting cities in 2018 (UNWTO, 2019). The geographical difference that Antalya provides with a coastal length of $640 \mathrm{~km}$ gives a great advantage and increases the attractiveness of tourism activities especially in terms of marine tourism. In addition, the fact that it is the world leader in this field with 202 Blue Flag beaches (Blue Flag, 2020) makes it more preferred by tourists in sea tourism plans.

Today, millions of tourists visit Antalya city centre and around touristic towns. Antalya is one of the districts where the boarding house first observed in Turkey. In addition, it is a touristic region that hosts foreign tourists free of charge in their homes in the first years of tourism and brings the concept of "guest tourist" to the literature (Uslu, 2018).

There are many activities for tourists coming to Antalya. One of these activities is the yacht tours organized for tourists.

Yacht tourism has become an increasingly popular activity all over the world in recent years. The most important reason for this popularity is the desire of people to be in touch with nature and to realize the holiday-sports couple together. Turkey, with bays in the Aegean and Mediterranean yacht tourism is a very advantageous position in terms of potential. Turkey has produced various policies for the development of this sector since the 1970s and in 1982 the Tourism Incentive Act No. 2634 was enacted (Altınkaynak \& Doğan, 2020). In this context, this law has played a big part in bringing the tourism sector to its current state, and marina has undertaken a serious mission in order to evaluate the demand for yacht tourism as a requirement of the country's tourism policies.

\section{Yacht tourism in the "new normal"}

The COVID-19 pandemic has caused devastating financial impacts on the tourism industry, and these effects are seen to be increasing (Ekren et al., 2020; Ayyıldız, 2020). Although countries offer important economic packages in order to reduce these effects, there is a global recession in the tourism sector as in many other sectors (Çitak \& Çalış, 2020). Studies point to serious customer and passenger losses, thus economic losses and unemployment after the pandemic, and state that there will be radical changes in the sector (Akça, 2020; Acar, 2020; Kiper et al., 2020; Demir et al., 2020; Eğri \& Doğaner, 2020). Tourism mobility has taken a serious hit, especially with the implementation of travel restrictions. Revenues of many enterprises operating in the tourism sector decreased and tourism-based health, accommodation and transportation expenditures contracted, but most of the fixed expenses remained (İbiş, 2020; Soylu, 2020; Gümüş \& Hacievliyagil, 2020).

In research which evaluating the impact of the COVID-19 pandemic on tourism in Turkey; It is understood that tourists mostly cancel their reservations or consider rural tourism options such as summer resorts, bungalows or plateaus where there will be less interaction between people and social distance is high (Acar, 2020; Özçoban, 2020; Alaeddinoğlu \& Rol, 2020; Yenişehirlioğlu \& Salha, 2020; Zoğal \& Emekli, 2020; Çitak \& Çalış, 2020). Because in this period, safety, security and stability are the prerequisites for foreign tourists, especially for vacation choices (Şahin \& Güzel, 2020). Tourists who make their holiday plans, on the other hand, in the pandemic conditions in their location; It is observed that their interest, excitement, curiosity and feelings of liking to decrease and they do not feel ready to spend more money (Akbaba, 2020). With the increase in the severity of the epidemic, it is observed that 
expenditures related to entertainment, travel and tourism have decreased sharply (Gössling et al., 2020; Chen et al., 2020). On the other hand, the continuing risk in the New Normal period; it causes tourists to avoid the crowd, increase the demand for rural areas, trigger the sea demand and increase the interest in holiday types where nature-based optimum satisfaction elements such as yacht tourism will be preferred more (Aydın \& Doğan, 2020; Özdemir, 2020; Ranasinghe et al., 2020). This situation has the potential to bring about radical changes in tourism services and shows that there will be serious trend changes in tourism product diversity (Özdemir, 2020). In addition, it is estimated that after the epidemic, people will participate in tourism activities again and with high motivation (Kiper et al., 2020). It can be said that trips where fewer groups come together, transportation and entertainment vehicles that provide the same size but low capacity service will be preferred, and a tourism understanding where hygiene is at the forefront (Demir et al., 2020; Özdemir, 2020).

In this process, in which the new understanding of tourism will be destinations based on nature and culture and the demand for alternative tourism types will increase; especially in countries like Turkey is expected to take place among countries which are in an advantageous position in the marine tourism (Özçoban, 2020). At the same time, it is anticipated that interest in environment and nature friendly practices may increase, and types such as yacht tourism, rural tourism, health, culture and diving tourism will be preferred more (Crossley, 2020; Aydın \& Doğan, 2020). In this sense, it is understood that yacht management and marinas still have a relative advantage over other activities in the tourism sector. Therefore, prepandemic innovation activities and performance enhancement activities (Öztürk et al., 2013; Temizkan \& Timur, 2019) should be implemented with a rapid adaptation to the New Normal.

\section{Methodology}

Purpose and benefit of the research)

The purpose of this research is to reveal to what extent the yacht enterprises operating in X Marina, which is one of the most important symbols of Antalya, were affected by the COVID-19 process and the results of this effect. In this sense, it is thought that the research results will contribute to the literature in terms of determining the effects of COVID-19 on yacht tourism and will give clues to similar yacht management managers.

\section{Limitations of the Research}

The research was carried out in a marina operating in Antalya due to the difficulty of reaching all yacht businesses due to time and cost constraints and the most important factor, COVID-19 restrictions. Local and foreign tourists also show great interest to yacht enterprises operating in a marina in Antalya, which is always at the forefront in national and international promotions for Antalya Province. In this context, it is thought that a study to be carried out Antalya X Marina will provide significant contributions to the marine tourism literature and guide the sector. The most important limitation of this research is that it has been conducted on yacht enterprises and daily boat tour operating in a single marina. A similar research can be carried out in a way to cover the boats and diving boats operating in the existing marinas in the Mediterranean, Aegean and Marmara Regions and making blue cruise voyages. Comparison can be made with each other.

\section{Method}

In this study, quantitative research method was used to achieve the aims of the research and face to face questionnaire technique was used. Data collection by questionnaire was carried out in September-October 2020. During the data collection process, both the researcher and the participants used masks and $2 \mathrm{~m}$ social distance rule has been observed. Each participant was asked to use his own pen as much as possible and when it was not found, the pen was given and taken and disinfected. Collected questionnaire forms were kept for 48 hours with a precautionary measure.

The research's Likert scale questions were prepared by taking the opinions of 9 experts and 5 academicians working in the field of yacht management. The questionnaire form, which was created in line with the information obtained after the experts and academic opinions, was presented to the expert opinion again. It has been determined that the questions on the subject reflect the effects of the Covid-19 process on daily tour and yacht operations at an appropriate and sufficient level and will measure the research subject correctly. To test the research questions, a pretest was applied to 10 yacht operators. After the expert opinion, Evci and Aylar (2017) recommend reaching approximately $5 \%$ of the main population and performing a pre-test. As a result of the pre-test, Croanbach Alpha coefficient was 0.816; Total Variance Explained - Extraction Sums of Squared Loadings-Cumulative was $87.298 \%$. 
The questionnaire consists of two parts, the first part includes questions on demographic characteristics, and the second part includes questions on the effects of COVID-19 on yacht management. In this section, the participants were asked to answer the related questions on a 5-point Likert scale with 1: Strongly Disagree, 5: Strongly Agree. Research questions were analyzed with the SPSS package program. The research was carried out in Antalya province. The main reason for choosing Antalya for the research is that it is one of the provinces where yacht harbor management has developed

\section{Research Hypotheses}

$\mathrm{H} 1$ : There is a meaningful relationship between the general exposure level of the daily tour yacht enterprises Antalya X Marina from the COVID-19 process and the concerns of the operators about the future of the sector.

$\mathrm{H} 2$ : There is a significant relationship between the general exposure level of the daily tour yacht enterprises Antalya X Marina from the COVID-19 process and the pricing policies of the operators.

H3: There is a meaningful relationship between the general exposure level of the daily tour yacht enterprises Antalya X Marina from the COVID-19 process and the fundraising policies of the operators.

$\mathrm{H} 4$ : There is a significant relationship between the general exposure level of the daily tour yacht enterprises Antalya X Marina from the COVID-19 process and customer acquisition.

H5: There is a meaningful relationship between the general exposure level of the daily tour yacht enterprises Antalya X Marina from the COVID-19 process and the increase in operating costs.

\section{The sample and Full Count Initiative}

The sample of this research is yacht enterprises (daily tourist trip, touristic fishing, diving and dolphin observing tours) operating in Antalya X Marina and making daily tours. In this context, there were 96 boats capacity located in the port, and the non-random sampling method was applied due to the limitations of COVID-19, time and cost constraints, workload and some boat owners' unwillingness to answer the questionnaire, and the respondents were selected with the easy sampling method. A questionnaire was applied to 37 yacht enterprises that receive permanent, temporary service also previously served from the marina in total. Özen and Gül (2007); They stated that in some field studies, the confidence in the results of the study based on a sample size of at least 30 can be as high as the confidence in the findings of a study with a large sample. In addition, as a rule of general, having at least 30 participants in correlation studies is considered reasonable. It may be deemed appropriate to have at least 20-50 participants in screening studies for small main masses (Gall et. al, 2003; Koç Başaran, 2017).

\section{Results}

\section{Demographic Characteristics of Respondents}

All 37 boat owners / captains who answered the questionnaire are male. In terms of age; two of them are in the 26-35 age range, 11 are in the age range of $36-45,15$ are in the age range of $46-55$ and five are in the age range of 56 and over. Four did not answer. 25 of the participants are boat owners, 12 of them are both boat owners and captains. 28 of 37 operators who answered the questionnaire have one boat and nine of them have two boats. In addition, 25 of their boats are within the scope of excursion, deign, and 12 of them have passenger engine status.

\section{The Impact of COVID-19 on Timed Boat Tours}

In the study, participants were asked to evaluate the effect of COVID-19 on timed boat tours and the following results were obtained.

Table 1: The impact of COVID-19 on timed boat tours

\begin{tabular}{|l|c|c|}
\hline & Frequency & $\mathbf{\%}$ \\
\hline Daily Boat Tour & 35 & 94.6 \\
\hline $\begin{array}{l}\text { Charter-Blue Cruise } \\
\text { Voyage }\end{array}$ & 2 & 5.4 \\
\hline Total & 37 & 100 \\
\hline Source: Authors
\end{tabular}

When Table 1 is examined, the majority of the respondents (94.6\%) think that the type of yacht management that is most affected by the COVID19 process is the day tour businesses. The rate of those who think that the blue cruise voyage is affected the most is $5.4 \%$.

\section{The Scale's Test of Validity}

In order to test the validity of the scale used in the study, an exploratory factor analysis was performed to look at Kaiser-Meyer-Olkin (KMO), Bartlett's Test of Sphericity and Total Variance Explained - Extraction Sums of Squared LoadingsCumulative values and the following results were found in Table 2.

Table 2: KMO and Bartlett's Testa ${ }^{\mathrm{a}}$

\begin{tabular}{|l|l|c|}
\hline \multicolumn{2}{|l|}{ KMO Measure of Sampling Adequacy } & .566 \\
\hline \multirow{2}{*}{$\begin{array}{l}\text { Bartlett's Test of } \\
\text { Sphericity }\end{array}$} & Approx. Chi-Square & 211.601 \\
\cline { 2 - 3 } & df & 78 \\
\hline
\end{tabular}

Source: Authors 
In our study, KMO value was found to be 0.566 and Barlett Test was significant (0.000) at 78 degrees of freedom. Field (2013) stated that 0.50 should be the lower limit for the KMO test. The ranges determined for the $\mathrm{KMO}$ value are considered to be 0.5-0.7 normal, 0.7-0.8 good, 0.8-0.9 very good and excellent for values greater than 0.9 (Field, 2013; Alışır et. al, 2020). In this direction, it is expected that Bartlett's Test of Sphericity will be significant and the KMO test will be higher than 0.50 (Kaya, 2013). Total Variance Explained - Extraction Sums of Squared Loadings-Cumulative value was determined as $67.335 \%$.

\section{Evaluation of the Impact of COVID-19 Process on Yacht Operations}

The following questions have been directed to determine the level of exposure of the yacht enterprises operating Antalya X Marina and organizing daily tours from the COVID-19 process. Due to the face-to-face research and the related COVID-19 process and restrictions, the number of questions was tried to be kept at a minimum.

Table 3: The impact of COVID-19 process on yacht operations

\begin{tabular}{|l|c|c|c|}
\hline & N & Average & $\begin{array}{c}\text { Std. } \\
\text { deviation }\end{array}$ \\
\hline $\begin{array}{l}\text { We had to lower our daily tour } \\
\text { price. }\end{array}$ & 37 & 4.4865 & .60652 \\
\hline $\begin{array}{l}\text { Our bargaining power has } \\
\text { decreased against tourists who } \\
\text { prefer a yacht tour. }\end{array}$ & 37 & 4.4054 & .59905 \\
\hline $\begin{array}{l}\text { Our general yacht management } \\
\text { costs have increased. }\end{array}$ & 37 & 4.4865 & .65071 \\
\hline $\begin{array}{l}\text { We find it difficult to pay the } \\
\text { salaries of our yacht management } \\
\text { (sea + land) personnel. }\end{array}$ & 37 & 4.4324 & .76524 \\
\hline We cannot get loans from banks. & 37 & 4.1622 & .89795 \\
\hline $\begin{array}{l}\text { We find it difficult to find tourists } \\
\text { who want to take a yacht tour. }\end{array}$ & 37 & 4.2432 & .64141 \\
\hline $\begin{array}{l}\text { We are considering selling our } \\
\text { boats. }\end{array}$ & 37 & 4.5135 & .60652 \\
\hline $\begin{array}{l}\text { We are thinking of quitting yacht } \\
\text { management and moving to } \\
\text { another line of business. }\end{array}$ & 37 & 4.4054 & .64375 \\
\hline $\begin{array}{l}\text { Due to COVID-19, we have } \\
\text { difficulty finding yacht personnel. }\end{array}$ & 37 & 3.3784 & 1.23269 \\
\hline Fuel costs have increased. & 37 & 3.7027 & 1.07664 \\
\hline $\begin{array}{l}\text { COVID-19 affected us negatively } \\
\text { in general. }\end{array}$ & 37 & 4.3784 & 1.11433 \\
\hline $\begin{array}{l}\text { I do not see well the future of } \\
\text { yachting. }\end{array}$ & 37 & 4.0270 & .95703 \\
\hline $\begin{array}{l}\text { If COVID-19 processes continue } \\
\text { like this, I think many yacht } \\
\text { businesses will go bankrupt in the } \\
\text { future. }\end{array}$ & 37 & 4.1351 & .97645 \\
\hline $\begin{array}{l}\text { Reliability analysis was performed } \\
\text { for research questions and } \\
\text { Cronbach's Alpha coefficient was } \\
\text { determined as 0.749 }\end{array}$ & & & \\
\hline Sourc: Autors & & & \\
\hline
\end{tabular}

When Table 3 is examined, it is understood that the most important effect of COVID-19 on yacht enterprises operating Antalya X Marina is in the direction that boat owners 'intend to sell their boats' (4.51). The second is that the COVID-19 process affects prices and costs. According to this, it is understood that the bargaining power of the boat owners against the customers has decreased (4.40), they have difficulty in finding tourists (4.24) and therefore they have to decrease the prices (4.48). In addition, it is seen that the costs of enterprises increase (4.48) in the process. At the beginning of these costs, the difficulties experienced in the payment of bank loan debts, a great decrease in the profit rate compared to the previous years, the customers' demands for longer tours at lower prices and thus increase in fuel costs, difficulty in finding personnel and the demand for higher salaries due to this, and at the end of each boat tour.

In addition, according to Table 3 , it is understood that yacht business owners operating in X Marina do not see the future of yachting in this region positively due to COVID-19 and they think that many yacht businesses will go bankrupt in the future if COVID-19 continue like this. These results show that business owners are worried about the future.

Investigation of the Relationship between the General Exposure Level of the COVID-19 Process and the Factors Affected

Pearson correlation analysis was conducted to determine the relationship between the factors affected by the COVID-19 process of the daily tour yacht enterprises operating in a marina in Antalya and the following results were obtained.

When Table 4 is examined, it is seen that there is the highest level of relationship between the general level of exposure to COVID-19 and especially the concerns about the future. While there is a correlation of 0.669 between the statement "I do not see the well future of yachting " and the general level of influence, it is seen that there is a correlation of 0.667 between the statement "If COVID-19 process continue like this, I think many yacht businesses will go bankrupt in the future." This result shows that yacht operators are worried about the future. In addition, it is observed that there is a significant relationship between the general level of influence and monetary values. It is noteworthy that there is a correlation of 0.631 between the statement "we cannot get loans from banks" and the general exposure level, and a correlation of 0.419 between the statement "we had to reduce our daily tour price" and the general exposure level. However, a statistically significant relationship was not found 
Table 4: The relationship between the general exposure level of the COVID-19 process and the factors affected

\begin{tabular}{|c|c|c|}
\hline & & $\begin{array}{c}\text { COVID-19 } \\
\text { affected us } \\
\text { negatively in } \\
\text { general. }\end{array}$ \\
\hline \multirow[t]{2}{*}{$\begin{array}{l}\text { We had to reduce our daily tour } \\
\text { price. }\end{array}$} & $\begin{array}{c}\text { Pearson } \\
\text { Correlation }\end{array}$ & $.419(* *)$ \\
\hline & Sig. (2-tailed) & .010 \\
\hline \multirow[t]{2}{*}{$\begin{array}{l}\text { Our bargaining power has } \\
\text { decreased against tourists who } \\
\text { prefer a yacht tour. }\end{array}$} & $\begin{array}{c}\text { Pearson } \\
\text { Correlation }\end{array}$ & $.346(*)$ \\
\hline & Sig. (2-tailed) & .036 \\
\hline \multirow[t]{2}{*}{$\begin{array}{l}\text { Our general yacht management } \\
\text { costs have increased. }\end{array}$} & $\begin{array}{c}\text { Pearson } \\
\text { Correlation }\end{array}$ & -.069 \\
\hline & Sig. (2-tailed) & .683 \\
\hline \multirow[t]{2}{*}{$\begin{array}{l}\text { We find it difficult to pay the } \\
\text { salaries of our yacht } \\
\text { management (sea + land) } \\
\text { personnel. }\end{array}$} & $\begin{array}{c}\text { Pearson } \\
\text { Correlation }\end{array}$ & .324 \\
\hline & Sig. (2-tailed) & .050 \\
\hline \multirow[t]{2}{*}{$\begin{array}{l}\text { We cannot get loans from } \\
\text { banks. }\end{array}$} & $\begin{array}{c}\text { Pearson } \\
\text { Correlation }\end{array}$ & $.631(* *)$ \\
\hline & Sig. (2-tailed) & .000 \\
\hline \multirow[t]{2}{*}{$\begin{array}{l}\text { We find it difficult to find } \\
\text { tourists who want to take a } \\
\text { yacht tour. }\end{array}$} & $\begin{array}{c}\text { Pearson } \\
\text { Correlation }\end{array}$ & .140 \\
\hline & Sig. (2-tailed) & .410 \\
\hline \multirow[t]{2}{*}{$\begin{array}{l}\text { We are considering selling our } \\
\text { boats. }\end{array}$} & $\begin{array}{c}\text { Pearson } \\
\text { Correlation }\end{array}$ & -.172 \\
\hline & Sig. (2-tailed) & .308 \\
\hline \multirow[t]{2}{*}{$\begin{array}{l}\text { We are thinking of quitting } \\
\text { yacht management and moving } \\
\text { to another line of business. }\end{array}$} & $\begin{array}{c}\text { Pearson } \\
\text { Correlation }\end{array}$ & -.065 \\
\hline & Sig. (2-tailed) & .703 \\
\hline \multirow[t]{2}{*}{$\begin{array}{l}\text { Due to COVID-19, we have } \\
\text { difficulty finding yacht } \\
\text { personnel. }\end{array}$} & $\begin{array}{c}\text { Pearson } \\
\text { Correlation }\end{array}$ & $.338(*)$ \\
\hline & Sig. (2-tailed) & .041 \\
\hline \multirow[t]{2}{*}{ Fuel costs have increased. } & $\begin{array}{c}\text { Pearson } \\
\text { Correlation }\end{array}$ & -.019 \\
\hline & Sig. (2-tailed) & .909 \\
\hline \multirow[t]{2}{*}{$\begin{array}{l}\text { I do not see well the future of } \\
\text { yachting. }\end{array}$} & $\begin{array}{c}\text { Pearson } \\
\text { Correlation } \\
\end{array}$ & $.669(* *)$ \\
\hline & Sig. (2-tailed) & .000 \\
\hline \multirow[t]{2}{*}{$\begin{array}{l}\text { If COVID-19 processes } \\
\text { continue like this, I think many } \\
\text { yacht businesses will go } \\
\text { bankrupt in the future. }\end{array}$} & $\begin{array}{c}\text { Pearson } \\
\text { Correlation }\end{array}$ & $.667(* *)$ \\
\hline & Sig. (2-tailed) & .000 \\
\hline \multirow[t]{2}{*}{$\begin{array}{l}\text { COVID-19 affected us } \\
\text { negatively in general. }\end{array}$} & $\begin{array}{c}\text { Pearson } \\
\text { Correlation }\end{array}$ & 1 \\
\hline & Sig. (2-tailed) & \\
\hline
\end{tabular}

Source: Authors

between the statements regarding the increase in operating costs and gaining customers and the general level of influence. Accordingly, the $\mathrm{H}_{1}, \mathrm{H}_{2}$ and $\mathrm{H}_{3}$ hypotheses are accepted, and the $\mathrm{H}_{4}$ and $\mathrm{H}_{5}$ hypotheses are rejected.

\section{Conclusions}

Undoubtedly, one of the business lines most affected by COVID-19 in the world has been the sea tourism sector. This sector, unlike other types of commercial shipping, has had to suspend its operations worldwide to a large extent. In fact, some countries are prohibited from entering the territorial waters of international cruise ships. Daily tour yacht management, which is one of the important subfields of marine tourism and provides important foreign currency inflow to countries, has also been adversely affected by the COVID-19 crisis and continues to be affected. In this research; the level of exposure of the daily tour yacht enterprises operating in a marina in Antalya from the COVID-19 process has been tried to be revealed. Antalya X Marina and yacht enterprises one of Turkey's most important and most soughtafter holiday destinations, which is located in Antalya. It plays an important role in Turkey and Antalya's tourism promotion activities and is much sought after.

In the analyses conducted, it is understood that especially the entrepreneur boat operators are concerned about the future and they are in a pessimistic picture. They stated that if COVID-19 continues, they can quit entrepreneurship and sell their boats, they will continue to work as a captain outside of Antalya or Antalya with the qualification of yacht captain certificate and if it is impossible, they can switch to another business.

Likewise, most of the boat owners stated that they saw the future of yachting as dark due to COVID19 and that many businesses could go bankrupt all over the world. Although they had bargaining power against both customers and agents in the market in previous years, they stated that this year they had to reduce the tour prices only in order to cover the costs and pay the personnel wages on time. In addition, it is observed that they have difficulty in obtaining bank loans in order to maintain their current status and cannot meet their funding needs. In addition, it is understood that there are great difficulties in the payment of existing loan debts. A statistically significant correlation at $95 \%$ confidence interval was found between the general level of influence from the COVID-19 process obtained from the research results and the sense of anxiety for the future, mandatory price policies for COVID-19, difficulty in finding funds and difficulty in attracting customers to the business.

To be less affected by this process; differentiation strategies should be implemented in areas related to image and services rather than price discrimination and it is recommended that boat personnel should be regularly tested for COVID, and the measures taken for the COVID-19 process on boats, hygiene and cleanliness conditions should be especially emphasized in promotional activities. 
Social media should be used in the most effective way. It is necessary to continue the providing conveniences in rent payments to the marina, to provide long-term bank loans and to convenience existing payments. Besides, it is seen that some yacht enterprises in a marina have established a cooperative and business cooperated. That's why, it is recommended to continue the cooperatives, which are considered to keep yacht businesses alive and the cooperatives is one of the most important strategies that will enable and ensure the survival of yacht enterprises in $\mathrm{X}$ Marina during the COVID-19 process.

Consequently; it is seen that the government, municipality and marina management have made significant aid and contributions during Covid-19 pandemic process. In addition, it is thought that the strategies suggested above, especially the cooperatives, are one of the important stones of getting out of COVID-19 with the lowest damage for both Antalya X Marina and yacht businesses operating daily tours in different destinations and these are will be guide for them.

\section{References}

Acar, Y. (2020). Yeni Koronavirüs (COVID-19) Salgını ve Turizm Faaliyetlerine Etkisi. Güncel Turizm Araştırmaları Dergisi, 4(1), 7-21.

Akbaba, M. (2020). COVID-19 Salgını Kapsamında Turist Yorgunluğunun Turistlerin Satın Alma, Tavsiye Etme ve Daha Fazla Ödeme Niyetlerine Etkisinin Belirlenmesi. International Journal of Social Sciences and Education Research, 6(2), $225-240$.

Akça, M. (2020). COVID-19'un Havacilik Sektörüne Etkisi. Avrasya Sosyal ve Ekonomi Araştırmaları Dergisi, 7(5), 45-64.

Alaeddinoğlu, F., \& Rol, S. (2020). Covid-19 Pandemisi ve Turizm Üzerindeki Etkileri. Yüzüncü Yıl Üniversitesi Sosyal Bilimler Enstitüsü Dergisi, Salgın Hastalıklar Özel Sayısı, 233-258.

Alışır, Z. N., Deniz, L., \& İrez, O. S. (2020). Bilim Tarihi Tutum Ölçeği: Geliştirilmesi, Geçerlik ve Güvenirlik Çalışması. Trakya Eğitim Dergisi, 10(3), 835-853.

Altınkaynak, F., \& Doğan, Ö. (2020). Türkiye'deki Finansal Raporlama Çerçevelerine Göre Devlet Teşviklerinin Karşılaştırmalı Analizi: Turizm Sektörü Örneği. Journal of Accounting \& Finance, 86, 79-96.

Aydın, B., \& Doğan, M. (2020). Yeni Koronavirüs (COVID-19) Pandemisinin Turistik Tüketici Davranışları ve Türkiye Turizmi Üzerindeki Etkilerinin Değerlendirilmesi. Pazarlama Teorisi ve Uygulamaları Dergisi, 6(1), 93-115.
Ayyıldız, A. Y. (2020). COVID-19 Salgın Döneminde Otellerin Pazarlama Stratejileri: Kuşadası Örneği. Business \& Management Studies: An International Journal, 8(3), 3328-3358.

Blue Flag. (2020). the Blue Flag sites awarded around the world. Foundation for Environmental Education. https://www.blueflag.global

Chakraborty, I., \& Maity, P. (2020). COVID-19 outbreak: Migration, effects on society, global environment and prevention. Science of the Total Environment, 728, 138882.

Chebli, A., \& Said, F. Ben. (2020). The Impact of COVID19 on Tourist Consumption Behaviour: A Perspective Article. Journal of Tourism Management Research, 7(2), 196-207.

Chen, K., Enger, W., Yu, J., \& Zhang, C. (2020). Hitting the Road Again: How Chinese Travelers are Thinking about Their First Trip after COVID-19. In McKinsey \& Company.

Çıtak, N., \& Çalış, Y. E. (2020). COVID-19 Salgının Turizm Sektörü Üzerine Olan Finansal Etkileri. Ida Academia Muhasebe ve Maliye Dergisi, 3(2), 110-132.

Crossley, É. (2020). Ecological Grief Generates Desire for Environmental Healing in Tourism after COVID19. Tourism Geographies, 22(3), 536-546.

Demir, M., Günaydın, Y., \& Demir, Ş. Ş. (2020). Koronavirüs (Covid-19) Salgınının Türkiye'de Turizm Üzerindeki Öncülleri, Etkileri ve Sonuçlarının Değerlendirilmesi. International Journal of Social Sciences and Education Research, 6(1), 80-107.

Depellegrin, D., Bastianini, M., Fadini, A., \& Menegon, S. (2020). The effects of COVID-19 induced lockdown measures on maritime settings of a coastal region. Science of The Total Environment, 740, 140123.

Doumbia-Henry, C. (2020). Shipping and COVID-19: protecting seafarers as frontline workers. WMU Journal of Maritime Affairs, 19(3), 279-293.

Eğri, T., \& Doğaner, A. (2020). COVID-19 ve Ekonomik Kriz: Kobiler Özelinde Bir Değerlendirme ve Politika Önerileri. Ístanbul Ticaret Üniversitesi Sosyal Bilimler Dergisi, 19(37), 128-145.

Ekren, N., Aykaç Alp, E., \& Güner, Y. (2020). COVID-19 Salgın Dönemi Ekonomi Anketi: İşletmelerde Karşılaşılan Sorunlar ve Çözüm Önerileri. İstanbul Yeminli Mali Müşavirler Odası \& İstanbul Ticaret Üniversitesi.

Evci, N., \& Aylar, F. (2017). Ölçek Geliştirme Çalışmalarında Doğrulayıcı Faktör Analizinin Kullanımı. Sosyal Bilimler Dergisi, 4(10), 389412 . 
Field, A. (2013). Discovering statistics using IBM SPSS statistics (4th Edition). New Delhi: Sage Publications.

Gall, M. D., Gall, J. P. \& Borg, W. R. (2003). Educational Research (7th edition). USA: Pearson Education.

Gössling, S., Scott, D., \& Hall, C. M. (2020). Pandemics, Tourism and Global Change: a Rapid Assessment of COVID-19. Journal of Sustainable Tourism, 120.

Gümüş, A., \& Hacievliyagil, N. (2020). Covid-19 Salgın Hastalığının Borsaya Etkisi: Turizm ve Ulaştırma Endeksleri Üzerine bir Uygulama. Akademik Yaklassmlar Dergisi, 11(1), 76-97.

İbiş, S. (2020). COVID-19 Salgınının Seyahat Acentaları Üzerine Etkisi. Safran Kültür ve Turizm Araştırmaları Dergisi, 3(1), 85-98.

Kaya, M. F. (2013). Sürdürülebilir Kalkınmaya Yönelik Tutum Ölçeği Geliştirme Çalışması, Marmara Coğrafya Dergisi, 28,(7), 175-193.

Kiper, V. O., Saraç, Ö., Çolak, O., \& Batman, O. (2020). COVID-19 Salginıyla Oluşan Krizlerin Turizm Faaliyetleri Üzerindeki Etkilerinin Turizm Akademisyenleri Tarafindan Değerlendirilmesi. Balıkesir Üniversitesi Sosyal Bilimler Enstitüsü Dergisi, 23(43), 527-551.

Koç Başaran, Y. (2017). Sosyal Bilimlerde Örnekleme Kuramı. Akademik Sosyal Arastırmalar Dergisi, 5(47), 480-495.

Millefiori, L. M., Braca, P., Zissis, D., Spiliopoulos, G., Marano, S., Willett, P. K., \& Carniel, S. (2020). COVID-19 Impact on Global Maritime Mobility. ArXiv Preprint ArXiv:2009.06960, 1-13.

Özçoban, E. (2020). Koronavirüs' ün (Covid-19) Turizm Sektörü Üzerindeki Etkileri ve Türkiye'nin Kırsal Turizm Potansiyeli Üzerine Bir Analiz. Electronic Turkish Studies, 15(4), 853-866.

Özdemir, M. A. (2020). Covıd-19 Salgını Sonrası Alınan Önlemlerle Turizm: Muhtemel Senaryolar. Journal of Recreation and Tourism Research/JRTR, 7(2), 222-238.

Özen, Y. \& Gül A. (2007). Sosyal Ve Eğitim Bilimleri Araştırmalarında Evren-Örneklem Sorunu. Atatürk Üniversitesi Kazım Karabekir Ĕ̈itim Fakültesi Dergisi, (15), 394-422.

Öztürk, E., Mesci, M., \& Kılınç, İ. (2013). Yenilik Faaliyetlerinin İşletme Performansına Etkisi: Yat Limanları Üzerine Bir Değerlendirme. Girisimcilik ve Kalkınma Dergisi, 8(2), 97-118.

Ranasinghe, R., Damunupola, A., Wijesundara, S., Karunarathna, C., Nawarathna, D., Gamage, S. Ranaweera, A., \& Idroos, A. A. (2020). Tourism after Corona: Impacts of Covid 19 Pandemic and Way Forward for Tourism, Hotel and Mice Industry in Sri Lanka. SSRN, 1, 1-19.
Soylu, Ö. B. (2020). Türkiye Ekonomisinde COVID-19'un Sektörel Etkileri. Avrasya Sosyal ve Ekonomi Arastırmaları Dergisi, 7(6), 169-185.

Stannard, S. (2020). COVID-19 in the maritime setting: the challenges, regulations and the international response. International Maritime Health, 71(2), 85-90.

Şahin, İ., \& Güzel, F. Ö. (2020). Olumsuz Güncel Gelişmelerin ve Krizlerin Türk Turizmine Etkileri: Profesyonel Turist Rehberlerinin Değerlendirmeleri ve Sektörel Çözüm Önerileri. Istanbul Gelişim Üniversitesi Sosyal Bilimler Dergisi, 7(2), 257-280.

Temizkan, S. P., \& Timur, B. (2019). Marinalarda Hizmet Kalitesi: Marmaris Marinaları Üzerine Bir Araştırma. Safran Kültür ve Turizm Araştırmaları Dergisi, 2(3), 508-524.

TKYGM (Tersaneler ve Kıyı Yapıları Genel Müdürlüğü). (2020). COVID-19 Küresel Salgınının Sektörümüze Etkisi. T.C. Ulaştırma ve Altyapı Bakanlığı, Tersaneler ve Kıyı Yapıları Genel Müdürlüğü.

UNWTO. (2019). International Recommendations for Tourism Statistics (IRTS). World Tourism Organization.

https://www.unwto.org/statistic/basic-tourismstatistics

Uslu, F. (2018). Bin Yıllık Türk Yurdu Antalya Kaleici'nin Son Yillarda Turizmle Birlikte Oluşan Sosyo-Kültürel Değişimi. Atatürk Üniversitesi Sosyal Bilimler Enstitüsü Dergisi, 22(Özel Sayı), 811-831.

WPSP (World Ports Sustainability Program). (2020). COVID19 survey: one quarter of ports responding have an increased share of empty container handling. 21.12.2020. https://sustainableworldports.org

Yenişehirlioğlu, E., \& Salha, H. (2020). Covid-19 Pandemisinin Türkiye İç Turizmine Yansımaları: Değişen Talep Üzerine Bir Araştırma. İstanbul Ticaret Üniversitesi Sosyal Bilimler Dergisi, 19(37), 355-368.

Zoğal, V., \& Emekli, G. (2020). Türkiye'de COVID-19 Salgını Sürecinde İkinci Konutların Değişen Anlamları. International Journal of Geography and Geography Education, 42, 168-181. 


\title{
INFO PAGE
}

\section{The Impact of the COVID-19 Pandemic Process on Yacht Operators: Application on a Marina in Antalya}

\begin{abstract}
Since the COVID-19 pandemic emerged, it has had a noticeable negative impact on many sectors and markets, especially the health sector. Although the large scale consequences have not yet been fully determined, the pandemic; started to change business life, personal priorities and habits. Curfews and encouragement of people not to leave their homes disrupted yachting activities. For this reason, one of the business lines most affected by the pandemic in the world has undoubtedly been the marine tourism sector. In countries with many sub-areas for marine tourism, such as Turkey, also in the yachting business sector has experienced a significant decline compared to last years. In this study; the level of exposure of yacht businesses which daily tour organizer and operating in X Marina where in Antalya the one of the most important and sought-after holiday destinations of Turkey, from the COVID-19 pandemic process has been tried to be revealed. In the study, quantitative research method was used and face to face survey technique was used. The most important limitation of this research is that it has been conducted only on yacht enterprises and daily boat tour operating in a single marina. Research results were analyzed with SPSS package program. In the analysis made, it is understood that especially the entrepreneur boat operators are concerned about the future and they are in a pessimistic picture. They stated that if COVID-19 continues, they can quit entrepreneurship and sell their boats and switch to another line of business.
\end{abstract}

Keywords: COVID-19, Marina Tourism, Yacht Management

\section{Authors}

Full Name Author contribution roles

Contribution rate

Erdal Arlı: Conceptualization, Methodology, Software, Formal analysis, Investigation, Data Curation,

Author statement: Author(s) declare(s) that All procedures performed in studies involving human participants were in accordance with the ethical standards of the institutional and/or national research committee and with the 1964 Helsinki declaration and its later amendments or comparable ethical standards.

Ethics Committee Satatement: Ethics committee report is available for this research and it has been documented to the journal.

Ethics committee: İstanbul Üniversitesi Deniz Bilimleri ve İşletmeciliği Enstitüsü Yönetim Kurulu

Date of ethics committee decision: 14.04 .2021

Ethics committee decision number: 1 